\title{
Effect of magnetic water on yield and fruit quality of some mandarin varieties.
}

\author{
${ }^{1}$ Hamdy, A.E., ${ }^{1}$ Khalifa, S.M.and ${ }^{2}$ Abdeen, S.A. \\ ${ }^{1}$ Department of Horticulture, Faculty of Agriculture, Al-Azhar University, Cairo, Egypt. \\ ${ }^{2}$ Department of Soils and Water, Faculty of Agriculture, Al-Azhar University, Cairo, Egypt.
}

Corresponding Author: ashraf_ezat_1@yahoo.com

\begin{abstract}
The present study was carried out during the two successive seasons 2013 and 2014 on 5 years old two mandarin varieties namely Balady and Fremont (Citrus reticulate Blanco) to elucidate the effect of magnetic water treatments on yield and fruit quality. The results indicated that irrigating the trees of the two mandarin varieties with magnetic water had significantly increased yield $(\mathrm{kg} / \mathrm{tree})$ in comparison to that of control. Maximum yield $(\mathrm{Kg} / \mathrm{trees})$ was obtained from mandarin varieties were irrigated all over the growth seasons with magnetic water. In this regard Balady mandarin variety which was superior to those of Fremont one compared with control. The physical and chemical fruit characteristics of the two tested mandarin varieties were significantly improved in response to irrigation with saline water treated with magnetic in comparison to control that was irrigated with saline water too. More studies are needed to declare the influence of magnetic water on the growth, yield and fruit quality of different citrus varieties.
\end{abstract}

Key words: Citrus, Balady, Fremont, mandarin, magnetic water, fruit quality.

\section{Introduction}

Citrus species grown in Egypt occupy an area of 395731 feddan with annual production of 2786397 tons (FAO, 2012). Mandarin varieties occupy the second planted area after orange which reached $27.2 \%$ of citrus cultivated area and $21.7 \%$ of total citrus production (The Central of Horticulture Management 2011). Many factors are contributing nowadays in reduction of fruit yield of Citrus species in Egypt. One of these factors, is the salinity of soil which is expressed as a biotic stress factor. 2470000 feddan of the local irrigated areas suffer from salinization problems, water logging and sodicity (FAO, 2005). Salinity stress depresses plant growth and development at different physiological levels. The magnetic water technology has been cited in the literature and investigated since the beginning of the $19^{\text {th }}$ Century. The magnetic field (MF) stimulation the fruit trees growth of different citrus species and improved the fruit qualities (Aladjadjiyan, 2002). MF affected the various plant characteristics such as germination of seeds, root growth, rate seedlings growth, reproduction growth of the meristem cells and chlorophyll quantities (Reina et al., 2001).The researchers have shown that magnetic field changed the characteristics of cell membrane and caused some changes in cell metabolism. The magnetic field affected the various plant characteristics such as gene expression, protein biosynthesis and enzyme activities and caused various plant functions either plant organ or tissue (Goodman et al., 1995 and Atak et al., 2003). In addition, magnetic field increased yield of sunflower and soybean (Oldacay and Erdem 2002). Magnetic fields have been reported to exert a positive effect on the ripening of fruits (Boe and Salunke, 1963). Short-day strawberry plants treated with MF in heated greenhouse conditions showed an increase in fruit yield per plant (Esitken and Turan, 2004).

Balady and Fremont mandarin varieties grown in new reclaimed soils are suffering from soil salinity and saline irrigation water. Therefore, the main goal of the present study is to determine the effect of the magnetic water irrigation on yield and fruit quality in comparison to those irrigated without subjecting the irrigation water to magnetic field.

\section{Materials and Methods}

This study was carried out during the two successive seasons of 2013 and 2014 on Balady and Fremont mandarin trees (Citrus reticulate Blanco) five years old grown in sandy soil. The soil samples collected from a private orchard located at Alsalehia Algadeeda, Alsharkia Governorate, Egypt. The two mandarin cultivars were budded on Volkamer lemon (Citrus volkameriana Ten. and Pasq.) rootstock. The trees were planted at $3 \times 5$ meters apart for Balady and $1.5 \times 5$ for Fremont mandarin trees and received adequate fertilizers, irrigated through drip irrigation system and subjected to the same cultural practices followed in the orchard.

Eighteen trees for each mandarin variety nearly similar in growth were devoted to collect the fruit samples at harvest time in order to determine the fruit chemical and physical characteristics under the effect 
of magnetic water. The fruit samples were collected from thirty six trees, which regarded as three trees per replicate, which each replicate contained thirty fruits similar in size. The obtained data were subjected to Duncan test. The following treatments were worked in two growth seasons 2013 and 2014.

I: Control treatment where the trees were irrigated with normal water.
I: The tree were irrigated with magnetic water.

Soil samples that were collected from both treatments were air dried and ground so that the soil particles can pass through $2 \mathrm{~mm}$ sieve holes. Similarly, water samples were collected before and after magnetizing effect were prepared for determination of water $\mathrm{pH}$, soluble cations and anions (meq/L), EC, available N, P and K (Klute, 1986 and Page et al., 1982).

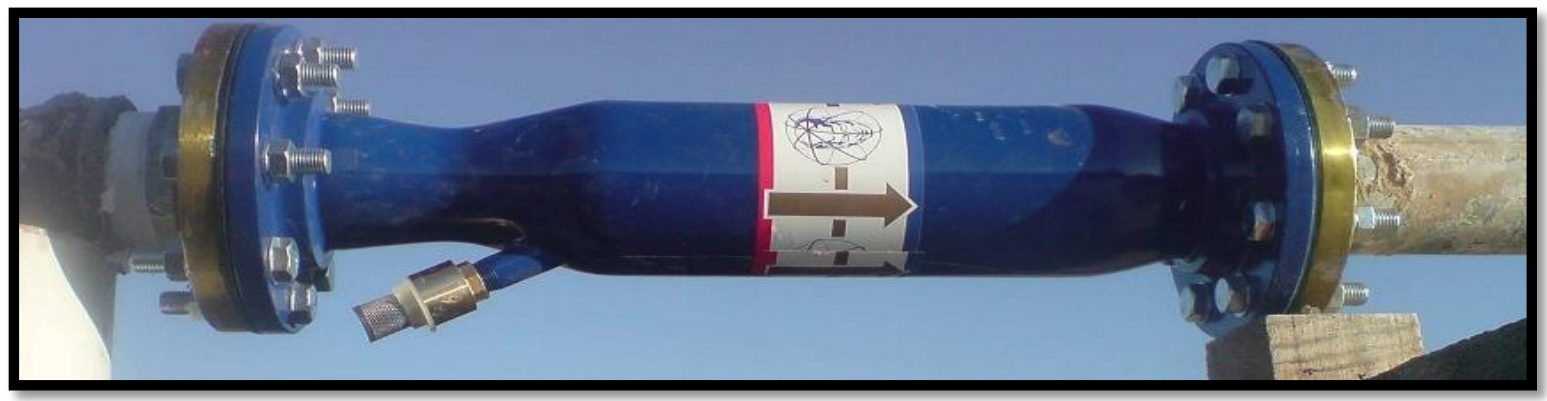

Fig. 1. Magnetic water conditioner.

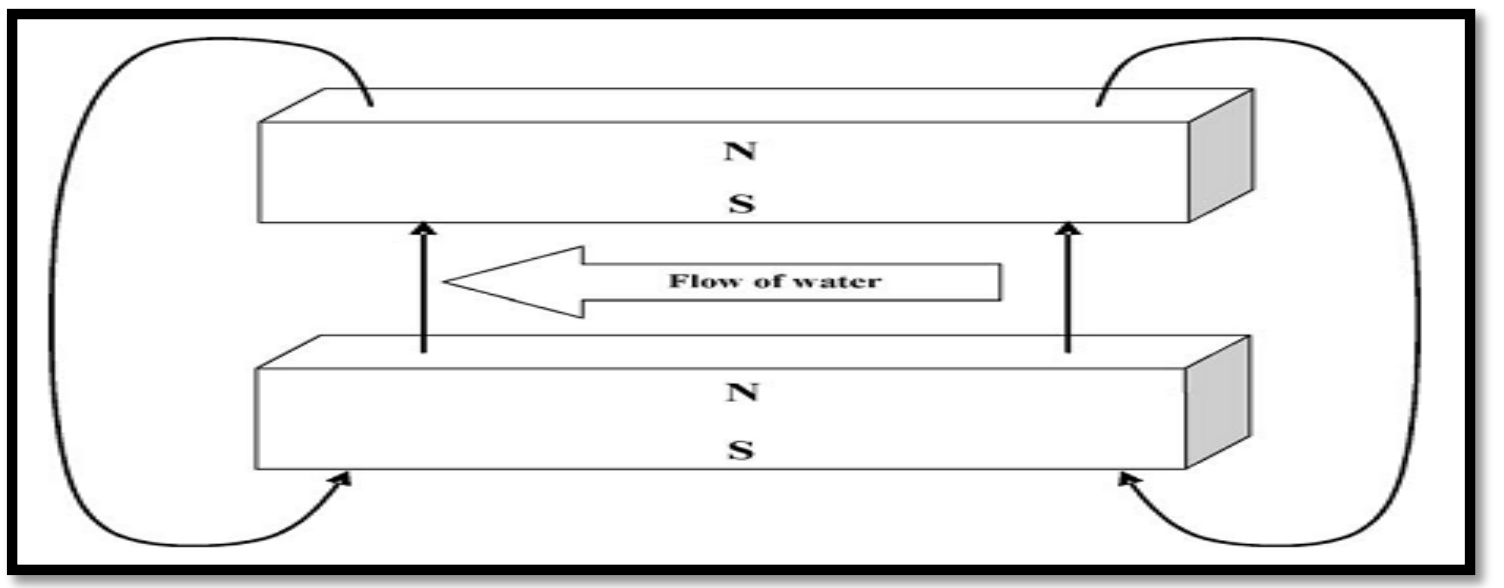

Fig. 2. Schematic of magnetic fields and direction of water flow during the magnetic treatment (Maheshwari and Grewal 2009).

\section{Measurements:}

The fruit yield harvest: fruit yield harvesting was achieved on $15^{\text {th }}$ December and the increment in yield of fruit under the effect of magnetism was compared with the control:

Fruit yield increment $(\%)=$

Fruit yield (kg)/treatment - Fruit yield (kg)/ control

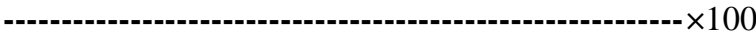

Fruit yield $(\mathrm{kg}) /$ control

Fruit physical characteristics: Samples of 10 fruits/tree were collected at harvesting date from each treatment to determine some fruit physical characteristics such as fruit weight $(\mathrm{g})$, fruit volume $\left(\mathrm{cm}^{3}\right)$, fruit pulp weight $(\mathrm{g})$, fruit peel weight $(\mathrm{g})$ and peel thickness $(\mathrm{cm})$ and juice volume of fruit $(\mathrm{ml})$.

Fruit firmness expressed as Newton (N) was measured using pressure tester (digital force-Gouge ModelIGV-O.SA to FGV-100A. Shimpo instruments).

Fruit biochemical characteristics: At harvest, samples of twenty fruits per tree were devoted to determine the following biochemical characteristics.

Total soluble solids (T.S.S. \%) of the fruit was determined by using Zeiss hand refractometer.

Total acidity (\%) was determined in fruit juice as percentage of anhydrous citric acid according to (A.O.A.C, 2000). 
Total soluble solids/acid ratio was calculated from the values of total soluble solids divided by values of total acids.

Ascorbic acid (Vitamin C) was calculated as mg/100 $\mathrm{ml}$ juice according to (A.O.A.C, 2000).

Statistical analysis: A complete randomized block design was followed and the analysis of variance (ANOVA) was performed using one way ANOVA Costat software according to Stern (1991), and the means were differentiated using Duncan multiple range test at 5\% level (Duncan, 1955).

\section{Results and Discussions}

\section{Soil properties}

Data in tables (1 and 2) showed that the magnetic treatment of irrigation water had slightly affected on soil $\mathrm{pH}$. The $\mathrm{pH}$ value decreased from 8.1- 8.02. On the other hand, the EC value increased from $0.42-0.85$ $\mathrm{dS} / \mathrm{m}$.Also, there are an increasing in organic matter (OM) and cation exchange capacity (CEC) values. The data showed that the present results are matching those reported with Mohamed (2013), who found that the use of magnetically treated irrigation water reduced soil $\mathrm{pH}$ and increased the EC values and available $\mathrm{P}$. Concerning of soluble cations and anions it could be seen that, the soluble ions were increased due to the magnetizing process compared with control. In this concern Hilal et al, (2002) observed that the magnetized water led to lowering soil alkalinity and dissolving slightly soluble salts such as carbonates, phosphates and sulfates. However, the degree of effectiveness of magnetized water on soil salinity and ionic balance in soil solution depended greatly on the travelling distance of magnetized water along the drip irrigation lines. Regarding to the effect of magnetic water on available NPK in the soil after harvest, the data present in table (2). Data showed that the use of magnetical irrigation water increased soil availability $\mathrm{N}$ and $\mathrm{P}$. while a reduction of $\mathrm{K}$ under using the magnetic water. In this concern, Noran et al. (1996) and (Maheshwari and Grewal 2009) observed differences in the concentrations of $\mathrm{N}, \mathrm{P}, \mathrm{K}$ in soils irrigated with magnetically treated water when compared to those treated with normal water. They argued that magnetic treatment of water might cause a slowdown of the movement of minerals, probably due to the effect of acceleration of the crystallizations and precipitation processes of the solute minerals. Magnetic treatment of water may be influenced desorption of $\mathrm{P}$ and $\mathrm{K}$ from soil adsorbed $\mathrm{P}$ on colloidal complex, and thus increasing its availability to plants, and thus resulting in an improved plant growth and productivity.

Table 1. Effect of magnetic water on some chemical and physical properties of the studied soil

\begin{tabular}{|c|c|c|}
\hline \multirow{2}{*}{ parameters } & \multicolumn{2}{|c|}{ values } \\
\hline & Control & Magnetic soil \\
\hline \multicolumn{3}{|c|}{ Some chemical properties } \\
\hline pH & 8.1 & 8.02 \\
\hline $\mathrm{EC} \mathrm{dS} / \mathrm{m}$ & 0.42 & 0.85 \\
\hline OM\% & 0.37 & 0.40 \\
\hline CECmeq/100g soil & 2.60 & 3.20 \\
\hline \multicolumn{3}{|c|}{ soluble cations and anions $(\mathrm{meq} / \mathrm{L})$} \\
\hline $\mathrm{Ca}^{++}$ & 1.28 & 2.00 \\
\hline $\mathbf{M g}^{++}$ & 0.90 & 1.50 \\
\hline $\mathrm{Na}^{+}$ & 1.85 & 3.90 \\
\hline $\mathbf{K}^{+}$ & 0.30 & 0.37 \\
\hline $\mathrm{CO}_{3}=$ & 0.00 & 0.00 \\
\hline $\mathrm{HCO}_{3}^{-}$ & 1.60 & 2.30 \\
\hline $\mathrm{Cl}^{-}$ & 1.90 & 2.70 \\
\hline $\mathrm{SO}_{4}=$ & 0.83 & 2.77 \\
\hline \multicolumn{3}{|c|}{ Available macro nutrients(mg/kg) } \\
\hline $\mathbf{N}$ & 25.5 & 30.0 \\
\hline $\mathbf{P}$ & 8.0 & 10.0 \\
\hline $\mathbf{K}$ & 55.0 & 43.0 \\
\hline \multicolumn{3}{|c|}{ Particle size distribution } \\
\hline$\%$ Sand & 76.5 & 73.6 \\
\hline$\%$ Silt & 16.85 & 17.9 \\
\hline$\%$ Clay & 6.65 & 8.5 \\
\hline Textural class & Loamy sand & Loamy sand \\
\hline
\end{tabular}


Table 2. Some characteristics of the used irrigation water before and after magnetizing.

\begin{tabular}{|c|c|c|c|c|c|c|c|c|c|c|c|}
\hline \multirow{2}{*}{ Parameters } & \multirow[t]{2}{*}{ pH } & \multirow{2}{*}{$\begin{array}{c}\text { EC } \\
\mathrm{dS} / \mathrm{m}\end{array}$} & \multicolumn{4}{|c|}{ Soluble cations (meq/L) } & \multicolumn{4}{|c|}{ Soluble anions (meq/L) } & \multirow{2}{*}{ SAR* } \\
\hline & & & $\mathbf{C a}^{++}$ & $\mathbf{M g}^{++}$ & $\mathrm{Na}^{+}$ & $\mathbf{K}^{+}$ & $\mathrm{CO}_{3}=$ & $\mathrm{HCO}_{3}$ & $\mathrm{Cl}^{-}$ & $\mathrm{SO}_{4}=$ & \\
\hline $\begin{array}{l}\text { Before } \\
\text { magnetizing }\end{array}$ & 7.31 & 1.30 & 2.80 & 1.50 & 8.70 & 0.50 & 0.00 & 4.70 & 5.60 & 3.20 & 5.93 \\
\hline $\begin{array}{l}\text { After } \\
\text { magnetizing }\end{array}$ & 7.21 & 2.00 & 3.97 & 2.10 & 11.28 & 0.78 & 0.00 & 7.60 & 8.00 & 2.53 & 6.47 \\
\hline
\end{tabular}

(*) SAR is sodium absorption ratio.

Yield (kg/ tree):

Data in Fig.2 showed that the irrigation of Balady and Fremont mandarin trees with magnetic water during growth season stages significantly increased yield $(\mathrm{kg} / \mathrm{tree})$ in comparison to that of control. The increase in yield attained nearly $35 \%$ in comparison with control. The results are in agreement with those of other workers who found that magnetic water treatment increased tree growth and fruit yield in horticulture plants (Boe and Salunke, 1963 and Ruzic et al., 1998).

\section{Season 2013}

50

40

30

20

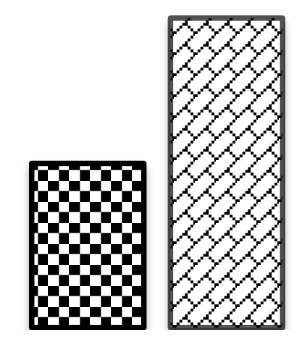

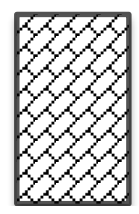

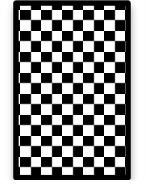

W Control $\square$ Magnetic water

Season 2014

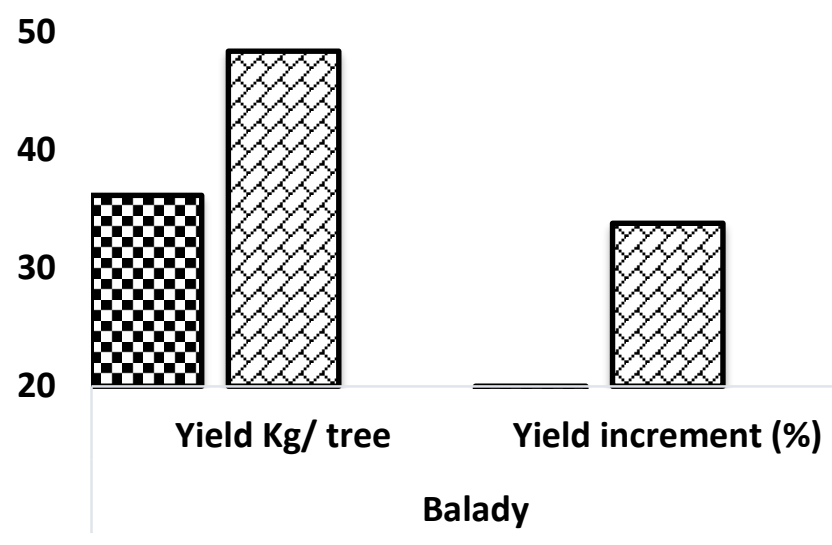

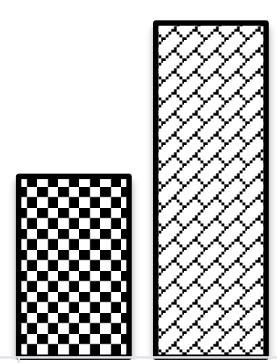

yield $\mathrm{Kg} /$ tree
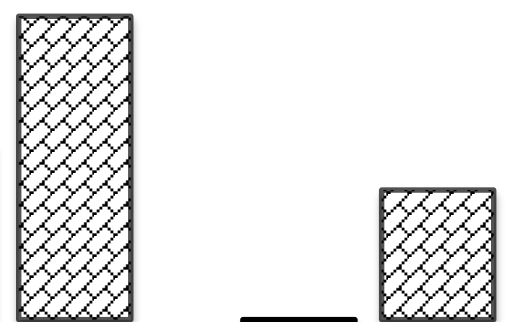

Fig. 2: Effect of magnetic water on fruit yield $(\mathrm{kg} / \mathrm{tree})$ of Balady and Fremont mandarin varieties at Seasons 2013 and 2014. 
The increase in fruit yield/tree can be attributed to the increase in fruit weight, fruit volume and number of fruits retained /tree at harvest as compared with those of control. Magnetic field affected the various characteristics of the plants like root growth, rate of shoot growth, reproduction and growth of the meristem cells and chlorophyll quantities in turn increased yield due to enhancing effect on the anabolic processes occurred in plant which improves the quality of fruits (Reina et al., 2001).

Magnetic treatment may be assisting to reduce the $\mathrm{Na}$ toxicity at cell level by detoxification of $\mathrm{Na}$, either by restricting the entry of $\mathrm{Na}$ at membrane level or by reduced absorption of $\mathrm{Na}$ by plant roots. Increased concentration of gibberellic acid-equivalents (GAs), indole-3-acetic acid (IAA) and trans zeatin were reported in sunflower plants under field up application of magnetic field (Turker et al., 2007). The magnetic treatment of water probably alters something in water, makes the water more functional within plant system and therefore probably influences the plant growth at cell level. Magnetic treatment of water may also affect phyto-hormone production leading to improved cell activity and plant growth (Maheshwari and Grewal 2009).

\section{Fruit physical characteristics. \\ Fruit weight and volume}

Magnetic water treatment significantly increased fruit weight $(\mathrm{g})$, fruit volume $\left(\mathrm{cm}^{3}\right)$, fruit pulp weight $(\mathrm{g})$, number of segments/fruit and fruit peel weight of the two varieties when compared with those of control in the two studied cultivars and seasons (Table 3). In the most cases, Balady mandarin was superior to those of Fremont one regarding the mentioned above characteristics. The stimulatory effect of magnetic water treatment on fruit weight and fruit volume reported in this study is in agreement with that obtained by De Souza et al. (2006) who found that magnetic treatments significantly increased the mean fruit weight, the fruit yield per plant, the fruit yield per area and the equatorial diameter of fruits of tomato in comparison with those of control. Irrigating plants with magnetic water is highly effective in enhancing growth characteristics, which suggests there may be a resonance-like phenomena which increase the internal energy of the plant that may be induce higher fruit weight (Vashisth and Nagarajan, 2008 and Shabrangi and Majd, 2009).. However, magnetic water treatment slightly increased fruit peel thickness of Balady and Fremont mandarin compared with control.

\section{Fruit height and diameter.}

Fruit dimensions (fruit height and diameter in $\mathrm{cm}$ ) significantly increased when the plant were irrigated through magnetic water treatment in comparison with that of control in the two mandarin cultivars and seasons (Table 3).The present results are confirmed by those of De Souza et al., (2006) who reported that irrigation by magnetic water significantly increased the diameter of tomato fruits in comparison with those of control. Similarly, Yamashita et al., (2004) found that the low magnetic water increased the length of Pea epicotyls compared to control. Negishi et al., (1999) stated that promotion of cell elongation under low magnetic field may relate to an increase of osmotic pressure in the cells.

\section{Fruit juice volume.}

Data in Table 4 cleared that magnetic water significantly increased fruit juice volume of Balady and Fremont mandarin cultivars in comparison with those of control in the two studied seasons. Fremont variety possessed the highest values in comparison to those of Balady one. The stimulatory effect of magnetic water on fruit juice volume reported in this study is in agreement with De Souza et al. (2006) who stated that irrigation with magnetic water significantly increased fruit weight and volume of tomato fruits in comparison with that of control.

\section{Seeds weight and numbers per fruit.}

The results in Table 4 revealed that irrigation with magnetic water significantly increased both seeds weight and numbers per fruit of Balady and Fremont mandarin varieties respectively in comparison with those of control. The results are in harmony with those of Hozayn and Abdul Qados, (2010) who reported that magnetic water significantly increased yield and seeds of chickpea plants in compared to that of control.

\section{Fruit firmness.}

Data in Table 4 showed that magnetic water significantly caused reduction in firmness of Balady mandarin fruits in comparison with control. Magnetic fields have been reported to exert a positive effect on plant growth and development (Martínez et al., 2000 and Ruzic et al., 1998), on the ripening of immature fruits (Boe and Salunke, 1963). In contrary, fruit firmness of Fremont trees significantly increased the response to magnetic water compared to those of Balady fruits which showed a significant decrease in fruit firmness if it was irrigated with magnetic water in the two studied seasons. 
Table 3. Effect of irrigation with magnetic water on some physical characteristics of Balady and Fremont mandarin varieties at 2013 and 2014 seasons.

\begin{tabular}{|c|c|c|c|c|c|c|c|c|c|c|c|c|c|c|}
\hline \multicolumn{15}{|c|}{ Cultivars } \\
\hline \multicolumn{8}{|c|}{ Balady } & \multicolumn{7}{|c|}{ Fremont } \\
\hline Character. & $\begin{array}{c}\text { Fruit } \\
\text { weight } \\
\text { (g) }\end{array}$ & $\begin{array}{c}\text { Fruit } \\
\text { volume } \\
\left(\mathbf{c m}^{3}\right)\end{array}$ & $\begin{array}{l}\text { Specific } \\
\text { gravity } \\
\left(\mathrm{g} / \mathrm{cm}^{3}\right)\end{array}$ & $\begin{array}{c}\text { Fruit } \\
\text { height } \\
(\mathrm{cm})\end{array}$ & $\begin{array}{c}\text { Fruit } \\
\text { diameter } \\
(\mathbf{c m})\end{array}$ & $\begin{array}{c}\text { Fruit } \\
\text { peel }(g)\end{array}$ & $\begin{array}{c}\text { Fruit } \\
\text { pulp } \\
\text { (g) }\end{array}$ & $\begin{array}{c}\text { Fruit } \\
\text { weight } \\
\text { (g) }\end{array}$ & $\begin{array}{c}\text { Fruit } \\
\text { volume } \\
\text { (cm3) }\end{array}$ & $\begin{array}{l}\text { Specific } \\
\text { gravity } \\
\left(\mathrm{g} \mathrm{cm}^{3}\right)\end{array}$ & $\begin{array}{c}\text { Fruit } \\
\text { height } \\
(\mathbf{c m})\end{array}$ & $\begin{array}{c}\text { Fruit } \\
\text { diameter } \\
(\mathbf{c m})\end{array}$ & $\begin{array}{c}\text { Fruit } \\
\text { peel } \\
\text { weight } \\
(\mathrm{g}) \\
\end{array}$ & $\begin{array}{c}\text { Fruit } \\
\text { pulp } \\
\text { (g) }\end{array}$ \\
\hline \multicolumn{15}{|c|}{ Season 2013} \\
\hline Control & $120.77 b$ & 136.04b & $0.89 a$ & $5.19 \mathrm{~b}$ & $6.63 b$ & $37.55 a$ & $81.54 b$ & $124.33 b$ & $122.91 b$ & $1.01 a$ & $5.73 a$ & $6.63 b$ & 33.92b & $90.41 b$ \\
\hline $\begin{array}{c}\text { Magnetic } \\
\text { water }\end{array}$ & 174.08a & 202.33a & $0.86 a$ & $6.22 \mathrm{~b}$ & $7.65 a$ & 37.93a & 132.84a & $145.53 a$ & $139.03 a$ & $1.05 a$ & $5.93 a$ & $7.03 a$ & $42.00 \mathrm{a}$ & $103.53 a$ \\
\hline \multicolumn{15}{|c|}{ Season 2014} \\
\hline Control & 124.07b & $124.47 \mathrm{~b}$ & $1.00 \mathrm{a}$ & $5.03 b$ & $6.57 b$ & $33.66 \mathrm{~b}$ & $88.93 b$ & $117.67 \mathrm{~b}$ & 97.33b & $1.21 \mathrm{a}$ & $4.83 b$ & $5.67 b$ & $24.33 b$ & 93.33b \\
\hline $\begin{array}{c}\text { Magnetic } \\
\text { water }\end{array}$ & $160.97 a$ & 173.77a & $0.93 a$ & 5.39a & $7.48 \mathrm{a}$ & 45.67a & 109.97a & 131.70a & $105.83 a$ & $1.24 a$ & $5.50 \mathrm{a}$ & $6.33 \mathrm{a}$ & $31.27 \mathrm{a}$ & $100.43 a$ \\
\hline
\end{tabular}

Means in each column followed by the same letter (s) are not significantly different at $5 \%$ level.

Table 4. Effect of irrigation with magnetic water on some physical characteristics of Balady and Fremont mandarin varieties at 2013 and 2014 seasons.

\begin{tabular}{|c|c|c|c|c|c|c|c|c|c|c|c|c|}
\hline \multicolumn{13}{|c|}{ Cultivars } \\
\hline \multicolumn{7}{|c|}{ Balady } & \multicolumn{6}{|c|}{ Fremont } \\
\hline $\begin{array}{l}\text { Character. } \\
\text { Treatments }\end{array}$ & $\begin{array}{l}\text { Juice } \\
\text { volume } \\
\left(\mathrm{cm}^{3}\right)\end{array}$ & $\begin{array}{l}\text { Seeds } \\
\text { weight } \\
\text { (g) }\end{array}$ & $\begin{array}{l}\text { Number } \\
\text { of } \\
\text { seeds/ } \\
\text { fruit }\end{array}$ & $\begin{array}{l}\text { Number of } \\
\text { segments/fruit }\end{array}$ & $\begin{array}{r}\text { Peel } \\
\text { thickness } \\
(\mathbf{c m})\end{array}$ & $\begin{array}{l}\text { Firmness } \\
(\mathbf{N})\end{array}$ & $\begin{array}{l}\text { Juice } \\
\text { volume } \\
\left(\mathbf{c m}^{3}\right)\end{array}$ & $\begin{array}{l}\text { Seeds } \\
\text { weight } \\
\text { (g) }\end{array}$ & $\begin{array}{l}\text { Number } \\
\text { of } \\
\text { seeds/ } \\
\text { fruit }\end{array}$ & $\begin{array}{l}\text { Number of } \\
\text { segments/fruit }\end{array}$ & $\begin{array}{r}\text { Peel } \\
\text { thickness } \\
(\mathrm{cm})\end{array}$ & $\begin{array}{l}\text { Firmness } \\
\text { (N) }\end{array}$ \\
\hline \multicolumn{13}{|c|}{ Season 2013} \\
\hline \multirow{2}{*}{$\begin{array}{l}\text { Control } \\
\text { Magnetic } \\
\text { water } \\
\end{array}$} & $47.67 \mathrm{~b}$ & $4.03 b$ & $25.50 a$ & $11.00 b$ & $0.32 \mathrm{a}$ & $23.43 a$ & $62.67 b$ & $1.42 \mathrm{~b}$ & $10.00 b$ & $9.67 a$ & $0.36 b$ & $20.81 b$ \\
\hline & $60.00 a$ & $6.05 a$ & $25.17 a$ & $12.67 a$ & $0.46 a$ & 19.38b & 68.33a & $1.90 \mathrm{a}$ & $12.67 a$ & $10.22 \mathrm{a}$ & $0.56 a$ & 23.35a \\
\hline \multicolumn{13}{|c|}{ Season 2014} \\
\hline Control & 35.13b & 3.17b & 21.33a & $11.00 b$ & $0.34 a$ & $30.77 a$ & $35.00 b$ & $1.20 \mathrm{~b}$ & $10.00 b$ & $9.67 a$ & $0.22 \mathrm{a}$ & 24.67b \\
\hline $\begin{array}{l}\text { Magnetic } \\
\text { water }\end{array}$ & $51.00 a$ & $5.27 a$ & $25.33 b$ & $12.00 \mathrm{a}$ & $0.44 a$ & $21.83 b$ & $54.00 a$ & $2.10 a$ & $16.00 \mathrm{a}$ & 11.33a & $0.38 \mathrm{a}$ & $27.67 a$ \\
\hline
\end{tabular}

Means in each column followed by the same letter (s) are not significantly different at $5 \%$ level. 
Fruit biochemical characteristics:

Total Soluble Solids (T.S.S. \%): Data in Table 5 cleared that total soluble solid of fruits increased when magnetic water was used in irrigating water both Balady and Fremont mandarin varieties in comparison with control. These results are in line with the findings of Selim (2008), who stated that TSS $(\%)$ of tomato fruit of fruit juice were increased by irrigating with magnetic water compared to that of control. The increase in TSS percentage may be due to increasing ions mobility and ions uptake that under magnetic water conditions which also leads to a better photosynthesis stimulation plants which showed an improvement of fruit characteristics (Pietruszewski, 1999). Moreover, magnetic field can change water properties, such as magnetized water increased plant chlorophyll content (Tian et al., 1989).Similarly, De Souza et al. (2006) indicated that significant increase in TSS (\%) might be due to the closed relationship between stomatal conductance and photosynthesis, that leading to an increase in photosynthesis process, which expressed as a result of bioenergetics structural excitement causing cell pumping and enzymatic stimulation. The increase in photosynthesis due to the greater interception of light and the greater amount of assimilates available for vegetative growth. This resulted in an increased SLA, which had a strong influence on crop growth. This agrees with the results of Hoff (1981) and Davies (1996), who found an increase in photosynthetic rate and influx of water as a result of magnetic treatments. Socorro et al. (1999) also reported a positive effect of magnetic treatment on leaf thickness in tomatoes crop leading to a noticeable increase in the thickness of the spongy tissue, and in the length and width of chlorophyllcontaining cells and the upper and lower epidermal cells.

Total Acidity\% and TSS/Acid ratio: Total acidity (\%) of fruits slightly decreased by using magnetic water in both Balady and Fremont mandarin varieties in comparison with that of control. However, TSS/Acid ratio of fruits increased under magnetic water treatment in both Balady and Fremont mandarin varieties in comparison with control (Table 5). This increase in TSS/Acid ratio may be due to the increasing in ions mobility and ions uptake which previously improved under magnetic water which leads to a better photosynthesis rate in plants (Pietruszewski, 1999).

Vitamin C: Vitamin C of fruits expressed as Ascorbic acid $/ 100 \mathrm{ml}$ of fruit juice significantly increased under magnetic water treatment in both Balady and Fremont mandarin varieties in comparison with that of control. The results are in line with findings of Selim (2008), who found that magnetic water increased vitamin $\mathrm{C}$ content in tomato fruits. The increase in V.C (Ascorbic acid $\mathrm{mg} / 100 \mathrm{ml}$ of fruit juice) in fruit juice at harvest time could be attributed to the increase in fruit weight and size and also to the increase in shoot growth and leaf area caused by magnetic treatment or may be due to irrigation with magnetized water caused a significant increase in the activities of the antioxidant enzymes over the control plants (Moussa 2011).

Table 5. Effect of magnetic water on some chemical characteristics of Balady and Fremont mandarin varieties at seasons 2014 and 2015.

\begin{tabular}{|c|c|c|c|c|c|c|c|c|}
\hline \multicolumn{9}{|c|}{ Cultivars } \\
\hline \multicolumn{4}{|c|}{ Balady } & & \multicolumn{4}{|c|}{ Fremont } \\
\hline Character. & TSS \% & $\begin{array}{l}\text { Total } \\
\text { acidity } \\
\%\end{array}$ & $\begin{array}{l}\text { TSS/acid } \\
\text { ratio }\end{array}$ & $\begin{array}{l}\text { V.C (mg } \\
\text { Ascorbic } \\
\text { acid } \\
\text { /100ml of } \\
\text { fruit juice) }\end{array}$ & TSS \% & $\begin{array}{l}\text { Total } \\
\text { acidity } \\
\%\end{array}$ & $\begin{array}{l}\text { TSS/acid } \\
\text { ratio }\end{array}$ & $\begin{array}{l}\text { V.C }(\mathbf{m g} \\
\text { Ascorbic } \\
\text { acid } / 100 \mathrm{ml} \\
\text { of fruit } \\
\text { juice) }\end{array}$ \\
\hline \multicolumn{9}{|c|}{ Season 2013} \\
\hline Control & $10.33 b$ & $1.17 a$ & $8.83 \mathrm{~b}$ & 33.31b & $10.00 \mathrm{~b}$ & $1.37 \mathrm{a}$ & $7.30 \mathrm{~b}$ & $42.67 \mathrm{~b}$ \\
\hline $\begin{array}{l}\text { Magnetic } \\
\text { water }\end{array}$ & $12.00 \mathrm{a}$ & $1.17 a$ & $10.25 a$ & $43.24 a$ & $11.67 a$ & $1.07 b$ & $10.91 a$ & $52.27 \mathrm{a}$ \\
\hline \multicolumn{9}{|c|}{ Season 2014} \\
\hline Control & $10.67 b$ & $1.60 \mathrm{a}$ & $6.66 \mathrm{~b}$ & $24.53 b$ & $9.67 \mathrm{~b}$ & $1.13 a$ & $8.53 b$ & $35.00 \mathrm{~b}$ \\
\hline $\begin{array}{l}\text { Magnetic } \\
\text { water }\end{array}$ & $11.00 a$ & $1.30 \mathrm{a}$ & $8.46 a$ & $36.80 \mathrm{a}$ & 11.33a & $1.08 b$ & $10.53 a$ & $40.60 \mathrm{a}$ \\
\hline
\end{tabular}

Means in each column followed by the same letter (s) are not significantly different at $5 \%$ level.

\section{References}

A.O.A.C. (2000). Official Methods of Analysis of the Association of Official Analytical Chemists $17^{\text {th }}$ ed. Arlngton Virgina, U.S.A.
Aladjadjiyan, A. (2002). Study of the Influence of Magnetic Field on Some Biological Characteristics of Zeamais. J. of Central Europ. Agric. 3(2). 89-94.

Atak, C., Emiroglu, O.", Aklimanoglu, S., and Rzakoulieva, A. (2003). Stimulation of 
regeneration by magnetic field in soybean (Glycine max L. Merrill) tissue cultures. J. Cell Mol. Biol., 2:113-119.

Boe, A.A., Salunke D.K., (1963). Effects of magnetic fields on tomato ripening. Nature 199, 91-92.

Carbonell, M.V., Martínez, E., Amaya, J.M., (2000). Stimulation of germination in rice (Oryza sativa L.) by a static magnetic field. Electro Magnetobiol 19 (1), 121-128.

Davies M.S., 1996. Effects of $60 \mathrm{~Hz}$ electromagnetic fields on early growth in three plant species and a replication of previous results. Bioelectromagnetics 17, 154-161.

De Souza, A., Garcia, D., Sueiro, L., Gilart, F., Porras, E., and Licea, L., (2006). Pre-sowing magnetic treatments of tomato seeds increase the growth and yield of plants. Bioelectromagnetics, 27, 247-257.

Duncan, D. B. (1955).Multiple range and multiple FTest Biometrics, 11: 1-42.

Esitken,A.,andTuran,M.(2004). Alternating magnetic field effects on yield and Plant nutrient element composition of strawberry(Fragaria xananassa cv. Camarosa). Acta Agric. Scand. Sect. BSoil Plant Sci. 54, 135-139.

Food and Agriculture Organization of the United Nation (2005). Land and Plant Nutrition Management Service Land and Water Development Division.

Food and Agriculture Organization of the United Nation (2012). Food and Agricultural commodities

production.http://faostat.fao.org/site/339/default.a spx.

Goodman, E.M., Greenabaum, B. and Morron, T.M. (1995). Effects of electromagnetic fields on molecules and cells. International Review of Cytology, 158: 279-325.

Hilal, M.H.; S.M. Shata, A.A.; Abdel-Dayem, and Hillal, M.M. (2002) Application of magnetic technologies in desert agriculture. III- Effect of Magnetized Water on yield and uptake of certain elements by citrus in relation to nutrients mobilization in soil. Egypt J. Soil Sci. 42(1),4355.

Hoff A.J., 1981. Magnetic field effects on photosynthetic reactions. Quat Rev Biophys 14(4), 599-665.

Hozayn, M. and Abdul Qados, A. (2010). Irrigation with magnetized water enhances growth, chemical constituent and yield of chickpea.Agric. Biol. J. N. Am., 1(4): 671-676.

Klute,A. (1986). Methods of Soil Analysis. Part 1. Physical and mineralogical Methods $2^{\text {nd }}$ Ed., Amer. Soc. Agron. Monograph No. 9 Madison,Wisconsin,USA.

Maheshwari BL, Grewal HS (2009). Magnetic treatment of irrigation water: Its effects on vegetable crop yield and water productivity. Agric Water Manage 96: 1229-1236.
Martínez, E., Carbonell, M.V., Amaya, J.M., (2000). A static magnetic field of $125 \mathrm{mT}$ stimulates the initial growth stages of barley (Hordeumvulgare L.). Electro Magnetobiol 19(3), 271-277.

Mohamed,I. A. (2013). Effects of magnetized low quality water on some soil properties and plant growth. Int. J. Res .Chem. Env. 13, 2: 140-147.

Negishi, Y., Hashimoto, A., Tsushima, M., Dobrota, C., Yamashita, M., \& Nakamura, T. (1999). Growth of pea epicotyl in low magnetic field implication for space research. Advances in Space Research, 23(12), 2029-2032.

Moussa,H. R. (2011). The Impact of Magnetic Water Application for Improving Common Bean (Phaseolus vulgaris L.) Production. New York Science Journal; 4(6):15-20].

Noran R, Shani R. Lin I. (1996). The effect of irrigation with magnetically treated water on the translocation of minerals in the soil. Magn. Electr. Sep., 7: 109-122.

Oldacay, S. and. Erdem, G. (2002).Evaluation of chlorophyll contents and peroxidaes activities in I (Helianthus annuusL.) genotypes exposed to radiation and magnetic field. Pak. J. of Appl. Sci., 2(10): 934-937.

Page, A. L., Miller, R.H. and Keeny, D.R. (1982).Methods of Soil Analysis. Part $\Pi$. Chemical and microbiological properties $2^{\text {nd }}$ Ed., Amer. Soc. Agron. Monograph No 9 Madison, Wisconsin,USA.

Pietruszewski, S.T., (1999). Effect of alternating magnetic field on germination, growth and yield of plant seeds. InzynieriaRolnicza 5(11), 209215.

Renia, F.G., Pascual, L.A., Fundora, I.A. (2001). Influence of a Stationary Magnetic Field on water relations in lettuce Seeds. Part II: Experimental Results. Bioelectromagnetics 22:596-602.

Ruzic, R., Berden, M., Jerman, I., (1998). The effects of oscillating electromagnetic fields on plants. Summary Report. Proc. First World Congress on the Bioeffects of Electricity and Magnetism on the Natural World, Madeira, UK, 1-6 October.

Selim, D. A. (2008). Response of some economic plants to magnetized water supply. MSc. Thesis. Minufiya Univ. Cairo, Egypt.

Shabrangi, A. and Majd, A. (2009). Effect of magnetic fields on growth and antioxidant systems in agricultural plants. PIERS Proceedings, Beijing, China, March 23-27.

Socorro A., Gil M., Labrada A., Díaz C., Lago E., 1999. Cell model of seed tissue treated with magnetic field. II International Symposium on Applied Nuclear and Related Techniques in Agricultura, Industry and Environment, La Habana, Cuba, 26-29 October.

Stern, R. D.(1991). Review of 'CoStat- Statutical Software' Experimental Agriculture, 27, pp 87 87. 
Turker, M., Temirci, C., Battal, P., Erez, M.E., 2007. The effects of an artificial and static magnetic field on plant growth, chlorophyll and phytohormone levels in maize and sunflower plants. Phyton Ann. Rei Bot. 46, 271-284

Tian WX, Kuang YL, and Mei ZP. (1989). Effect of magnetic water on seed germination, seedling growth and grain yield of rice. J Jilin Agric Univ., 11: 11-6.

Vashisth, A. and Nagarajan, S. (2008). Exposure of seeds to static magnetic field enhances germination and early growth characteristics in chickpea (Cicer arietinum L.). Bioelectromagnetics, 29:571-578.

Yamashita M., Tomita-Yokotani K., Hashimoto H., Takai M., Tsushima M., Nakamura T. (2004). Experimental concept for examination of biological effects of magnetic field concealed by gravity.Adv. Space Res. 34, 1575-1578. 


\section{تاثير الرى بالماء الممغنط على محصول وجودة ثمار بعض أصناف اليوسفى \\ 1أثنرف عزت حمدى و 1صبحى محمد خليفه و سيد عبد الرحمن عابدين

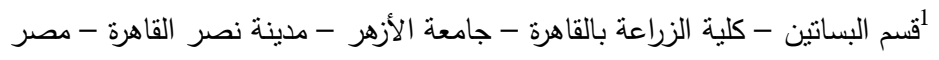

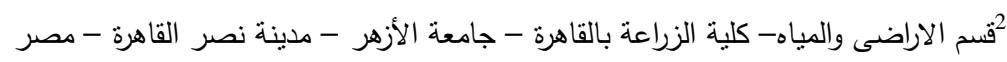

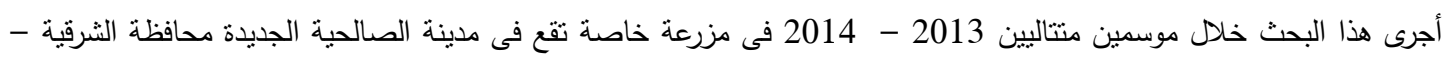

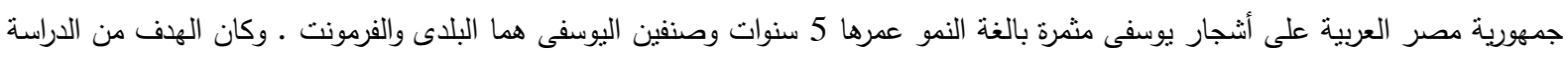

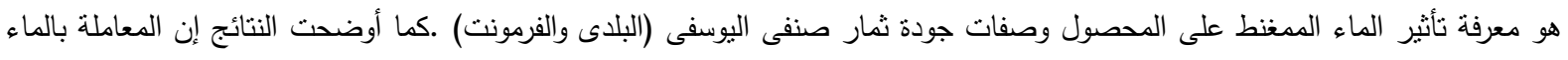

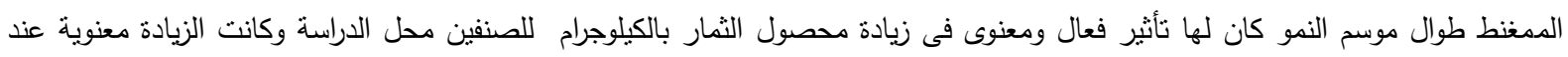

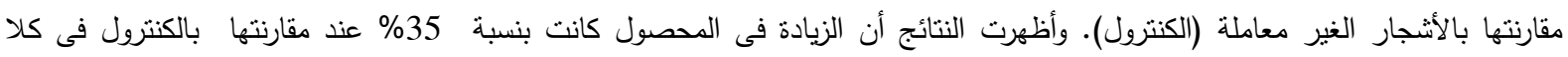

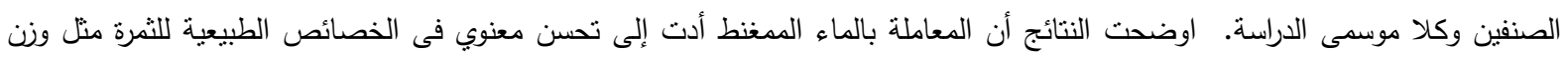

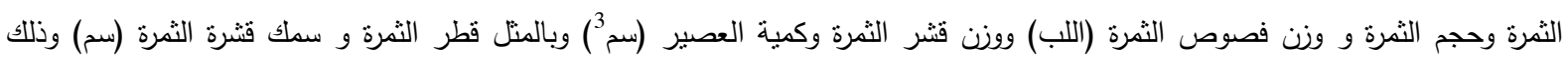

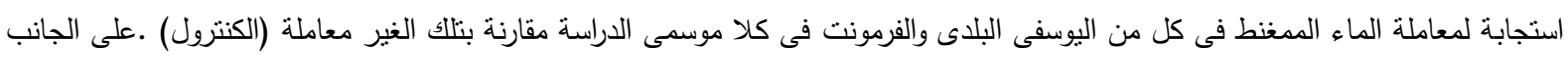

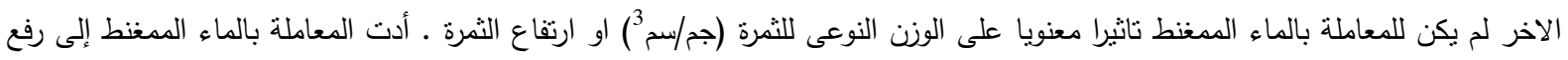

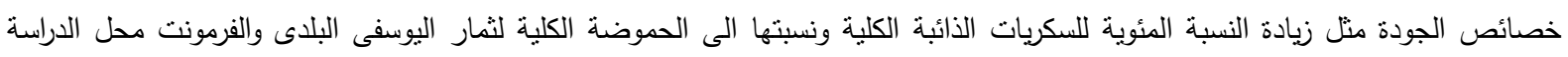
مقارنة بتلاك الغير معاملة (الكنترول). الكلمات الدالة : الموالح - اليوسفى (البلدى - الفرمونت) - المحصول -الماء الممغنط - جودة الثمار. 